\title{
KONFLIK PERADABAN SAMUEL P. HUNTINGTON (Kebangkitan Islam yang Dirisaukan?)
}

\author{
Oleh: Vita Fitria \\ (MKU - UNY)
}

\begin{abstract}
Abstrak
Istilah 'konflik peradaban' diperkenalkan Samuel Huntington dalam bukunya The Clash of Civilization and the Remaking of World Order (1996). Menurut Huntington, dengan berakhirnya Perang Dingin yang ditandai dengan runtuhnya ideologi komunisme, wilayah konflik meluas melewati fase Barat, dan yang mewarnainya adalah hubungan antara peradaban Barat dan non-Barat serta antarperadaban nonBarat itu sendiri. Huntington mengelompokkan negara-negara bukan atas dasar sistem politik ekonomi, tetapi lebih berdasarkan budaya dan peradaban. Ia mengidentifikasi sembilan peradaban kontemporer, yaitu, peradaban Barat, Cina, Jepang, Amerika Latin, Afrika, Hindu, Budha, Islam, dan Kristen Ortodoks. Benturan yang paling keras menurut Huntington - akan terjadi antara kebudayaan Kristen Barat dengan kebudayaan Islam. Tesis tersebut secara tidak langsung memperkuat asumsi sebagian besar ilmuwan Barat yang melihat Islam sebagai aggression and hostility (agresi dan ancaman). Pendek kata, bagaimana Barat menciptakan stereotipe-stereotipe simplistis yang menunjukkan wajah the rage of Islam.
\end{abstract}

\section{Pendahuluan}

Samuel P. Huntington, seorang profesor Ilmu Pemerintahan dan direktur Institut John M. Ulin untuk Studi-studi Strategis, Universitas Harvard (AS), mengemukakan dalam sebuah artikelnya bahwa politik dunia sekarang memasuki fase baru, dan para intelektual sudah berani mengembangkan visi-visi tentang apa yang akan terjadi misalnya saja visi berakhirnya sejarah, kembalinya lawan-lawan tradisional di antara negara bangsa, runtuhnya negara bangsa karena tarik-menarik yang disertai konflik antara tribalisme dan globalisme. Masing-masing visi ini menangkap aspek-aspek realitas yang muncul, tetapi semuanya tidak menyentuh aspek yang krusial dan sentral dari politik global yang mungkin akan terjadi dalam tahun-tahun mendatang. Huntington, dalam bukunya The Clash of Civilizations and The 
Remarking of Word Order, berpendapat bahwa dengan berakhirnya perang dingin sumber konflik utama yang dihadapi umat manusia tidak lagi masalah ideologi dan ekonomi, tetapi perbedaan kebudayaan.

Penulis mencoba mengelaborasi kembali pandangan Huntington, yang telah bertahun-tahun menjadi polemik bahkan juga di kalangan intelektual Amerika Serikat sebagai negara asalnya. Menurut Donald K. Emmerson, ide Huntington ini tidak mendapat angin di kalangan pejabat AS di Washington. Pemboman WTC yang terjadi tidak dilihat pemerintah Amerika sebagai serbuan peradaban Islam melawan peradaban Barat. Militan-militan Arab yang dituduh melakukan aksi teror itu dianggap sebagai pelaku lokal, dan bukan mewakili peradaban Islam secara keseluruhan (Emmerson, 1993: 49). Benarkah meletusnya perang AS-Irak 20 Maret 2003, pengeboman WTC 11 September 2001, atau konflik Hamas dan Israel di awal tahun 2009, cukup memberi signifikasi atas kebenaran prediksi Huntington tentang benturan peradaban khususnya Islam vis a vis Barat. Disertai uraian dan analisis, penulis akan coba menekankan dari perspektif Islam, sebagai salah satu peradaban yang dikonfrontasikan dengan Barat.

\section{Biografi dan Karya Samuel P. Huntington}

Samuel Phillips Huntington lahir di New York City, 18 April 1927 dan meninggal di Martha's Vineyard, Desember 2008 usia 81 tahun. Beliau adalah seorang ilmuwan politik Amerika Serikat, Seorang Guru Besar sekaligus Ketua Jurusan Ilmu Politik di Universitas Harvard dan Ketua Harvard Academy untuk Kajian Internasional dan Regional, di Weatherhead Center for International Affairs (http://id.wikipedia.org/wiki/Samuel_Huntington).

Tahun 1999-2000 ia berkerja untuk meneliti berbagai perubahan yang menonjol menyangkut persoalan identitas nasional Amerika dan implikasi-implikasi dari berbagai perubahan ini terhadap peran Amerika di dunia internasional. Bukunya, Political Order in Changing Societies yang ditulis tahun 1968, kerap dilihat sebagai cetak biru model demokratisasi yang mementingkan stabilitas. Buku tersebut telah digunakan secara luas sebagai salah satu buku teks untuk studi politik negara-negara berkembang.

Adapun tulisan Huntington tentang "Konflik Peradaban" semula berasal dari artikelnya dalam jurnal Foreign Affairs, edisi musim panas, 1993. Karena kritik dan tanggapan yang masuk cukup banyak, bahkan dari berbagai benua dan negara, maka pada tahun 1996 
diterbitkan dengan penambahan-penambahan baru yang dirasa mendasari teorinya tersebut dengan judul buku The Clash of Civilizations and The Remarking of World Order. Salah satu artikelnya Religion and the Third Wave juga telah memancing reaksi dari banyak kalangan, karena di situ ia menyebutkan bahwa Islam merupakan penghambat demokrasi. Selama tahun-tahun selanjutnya, Huntington tetap memfokuskan dirinya pada persoalan-persoalan identitas nasional, terutama identitas nasional Amerika (Huntington, 2004: 9).

Karya berikutnya adalah buku yang berjudul Culture Matters: How Values Shape Human Progress, yang disuntingnya bersama Lawrence Harrison, dan telah terbit pada bulan Mei 2000. Buku terakhirnya yang berjudul Who Are We? The Challenges to America's National Identity terbit Mei 2004. Dalam buku ini terutama Huntington menyoroti identitas Amerika sebagai bangsa permukim bukan imigran, hal ini berbeda dengan kebanyakan ahli yang melihat Amerika sebagai budaya imigran yang dicangkokkan dari tanah leluhurnya. Para pemukim dalam interaksinya harus membentuk identitas sendiri (Huntington, 2004: 10).

Di antara beberapa karyanya tersebut, buku The Clash of Civilizations merupakan buku yang menimbulkan banyak reaksi dari berbagai kalangan. Buku tersebut memperkirakan terjadinya perbenturan antarbudaya, seperti yang kemudian terjadi setelah peristiwa 11 September (pengeboman menara WTC di New York). Berbekal kerangka buku ini banyak orang melihat perang menumpas terorisme sebagai perbenturan kebudayaan Barat dan Timur, sesuai kerangka pikir yang dituliskan Huntington. Buku ini merupakan karya monumentalnya yang menjadi kontroversi dan memicu polemik di berbagai belahan dunia selama beberapa tahun.

\section{Latar Belakang Pemikiran}

Latar belakang pemikiran Huntington di awali dari satu hipotesis bahwa sumber fundamental dari konflik dalam dunia baru - yang dimaksud adalah dunia pasca perang dingin - pada dasarnya tidak lagi ideologi atau ekonomi, melainkan budaya. Masa Perang Dingin adalah konflik antara dua negara super power yang tidak lagi mendefinisikan diri masing-masing sebagai negara bangsa dalam pengertian klasik, tetapi mendefinisikan identitas masing-masing atas dasar ideologi yang mereka anut (komunis dan demokrasi liberal). Budaya akan memilah-milah manusia dan menjadi sumber konflik yang dominan. 
Pada akhirnya konflik politik global yang paling prinsipil akan terjadi antar bangsa dan antar kelompok adalah karena perbedaan peradaban mereka. Konflik peradaban akan menjadi fase terakhir dari evolusi konflik dalam dunia modern (Huntington, 1993: 11).

Huntington mengemukakan fase-fase historis dalam perubahan atau konflik tersebut dengan pengalaman Barat, dibagi menjadi tiga, yaitu:

1. Konflik antar raja

Yang merupakan konflik antara monarki absolut dan monarki konstitusional yang masing-masing pihak bertujuan untuk memperluas ketentuan birokrasi, angkatan bersenjata, kekuatan ekonomi merkantilis, dan terutama perluasan wilayah.

2. Konflik antarnegara bangsa

Setelah Revolusi Perancis, konflik bukan lagi atas nama raja-raja, melainkan antar negara bangsa. Seperti dikemukakan oleh R.R. Palmer, "The wars of kings were over; the wars of people had begun (Huntington, 1996: 52). Hal ini berlangsung terus sampai pecahnya Perang Dunia I.

3. Konflik antarideologi

Sebagai hasil dari Revolusi Rusia dan perlawanan terhadapnya, konflik antar bangsa kemudian melahirkan konflik antar ideologi. Pertama-tama antar ideologi komunisme, fasisme-nazisme, dan demokrasi liberal. Kekalahan fasisme-nazisme semakin meruncingkan konflik antara komunisme dan demokrasi liberal. Inilah yang kemudian disebut dengan konflik masa Perang Dingin (Huntington, 1993: 12).

Dengan berakhirnya Perang Dingin yang ditandai dengan runtuhnya ideologi komunisme, wilayah konflik meluas melewati fase Barat, dan yang mewarnainya adalah hubungan antara peradaban Barat dan non-Barat serta antar peradaban-peradaban non-Barat itu sendiri. Di sini rakyat dan pemerintah peradaban non-Barat tidak lagi menjadi objek sejarah seperti sasaran kolonialisme Barat, tapi bersama-sama Barat sebagai penggerak dan pembentuk sejarah (Huntington, 2004: 17).

\section{Peradaban dan Klasifikasi Huntington}

Peradaban adalah suatu entitas budaya. Huntington juga mendefinisikan lebih rinci lagi bahwa peradaban adalah pengelompokan tertinggi dari orang-orang yang tingkat identitas 
budaya paling luas yang dimiliki oleh orang sehingga membedakannya dari species lain. Ia dibatasi oleh unsur-unsur objektif, yaitu, bahasa, sejarah, agama, adat istiadat, lembagalembaga. Juga dibatasi unsur subjektif yaitu identifikasi diri dari orang-orang tersebut. Budaya dalam hal ini diwakili oleh berbagai wilayah, baik desa, daerah, kelompok etnis, kebangsaan, kelompok agama dan lain-lain yang semuanya mempunyai tingkat keragaman budaya yang berbeda-beda. Dari perbedaan inilah akan menuju pada satu persamaan yaitu menjadi sebuah peradaban.

Huntington mencatat ada sembilan peradaban besar di dunia yaitu: Barat, Konfusius, Jepang, Islam, Hindu, Cina, Amerika Latin, Kristen Ortodoks, dan Afrika. Dari pengertian peradaban yang diambil Huntington, dapat disimpulkan bahwa ia sebenarnya mencampur adukkan berbagai macam ukuran dalam memilah peradaban, antara lain dimensi letak atau posisi wilayah (Barat), dimensi ajaran (Konfusius), dimensi etnis (Slavia), dimensi negara (Jepang), dimensi agama (Islam) dan dimensi benua (Afrika).

Sebagai perbandingan, setidaknya terdapat dua paham yang berkaitan dengan 'peradaban' dan 'kebudayaan'. Pertama, pendukung mazhab Jerman atau Eropa Kontinental yang membedakan antara cultur (kebudayaan) dan civilisation (peradaban). Istilah peradaban sering digunakan sebagai persamaan yang lebih luas dari istilah "budaya" yang populer dalam kalangan akademis. Setiap manusia dapat berpartisipasi dalam sebuah budaya, yang dapat diartikan sebagai "seni, adat istiadat, kebiasaan atau kepercayaan, nilai, bahan perilaku dan kebiasaan dalam tradisi yang merupakan sebuah cara hidup masyarakat". Dalam artian yang sama, peradaban dapat berarti "perbaikan pemikiran, tata krama, atau rasa" (http://id.wikipedia.org/ wiki/Peradaban). Civilization lebih ditekankan pada persoalanpersoalan non abstrak, yang sifatnya materiil terutama yang menyangkut aspek-aspek mekanik dan high teknologi, dan kultur lebih menyentuh pada aspek-aspek nilai, ide, high culture, intelektual, moralitas atau aspek-aspek lain yang penekanannya lebih bersifat abstrak. Yang kedua adalah pihak-pihak di luar mazhab Jerman, termasuk Perancis dan Amerika yang tidak membedakan culture dan civilization, karena dianggap sebagai satu kesatuan yang melekat secara total (termasuk juga Huntington), sehingga lazimnya istilah civilization menjadi terjemahan Inggris dari kata kultur. 


\section{Faktor Penyebab Konflik Antarperadaban}

Secara tegas, Huntington mengemukakan ada enam alasan pokok mengapa benturan peradaban akan menjadi sumber konflik utama di masa pasca perang dingin ini (Huntington, 1993: 25-40). Alasan pertama, adalah kenyataan bahwa perbedaan antar peradaban tidak hanya riil, tapi juga mendasar. Peradaban terdiferensiasi oleh sejarah, bahasa, budaya, tradisi, dan yang lebih penting lagi, agama. Perbedaan agama melahirkan perbedaan dalam memandang hukum manusia dengan Tuhan, individu dan kelompok, warga dan negara, hak dan kewajiban, kebebasan dan sebagainya. Perbedaan ini tidak mesti melahirkan konflik, dan konflik bukan berarti munculnya kekerasan. Namun selama berabad-abad dalam catatan sejarah, perbedaan inilah yang menimbulkan konflik yang paling keras dan berkepanjangan. Huntington melihat bahwa sumber utama konflik dalam dunia baru bukanlah ideologi, politik atau ekonomi, tetapi budaya. Budaya dalam manifestasi yang lebih luas adalah peradaban, suatu unsur yang membentuk pola kohesi, disintegrasi dan konflik. Ia menilai bahwa perang antarklan, antarsuku, antaretnik, antaragama dan antarbangsa merupakan suatu fenomena umum. Perang Dingin adalah penyimpangan sejarah dan tidak substansial serta tak membahayakan. Perang Teluk I, menurut Huntington, adalah perang peradaban pertama pasca Perang Dingin. Meskipun ia mengidentifikasi sembilan peradaban kontemporer, namun hanya dua peradaban yang menjadi favorit pembahasannya yakni Barat dan Islam. Tujuh peradaban dunia lain adalah peradaban Cina, Jepang, Amerika Latin, Afrika, Hindu, Budha, dan Kristen Ortodoks. Huntington bahkan tidak memasukkan Yahudi sebagai peradaban (http://swaramuslim.net/more.php?id=A266010M).

Bila dilihat dari dimensi sejarah, argumentasi Huntington ini ada benarnya. Tapi di sisi lain sejarah juga menunjukkan bahwa suatu peradaban yang memiliki jangkauan universal seperti Islam dan Kristen, memiliki kekuatan integralistik yang terbatas. Sebagai contoh Islam yang tidak mampu membendung nasionalisme bangsa Kurdi yang ingin melepaskan diri dari Negara induknya yang juga Islam, terutama di Irak dan Turki. Atau konflik antara kelompok Katholik dan Protestan di Irlandia Utara yang berlangsung sejak abad 16. Begitu juga dengan disintegrasi Uni Sovyet yang terjadi bukan semata-mata karena perbedaan agama atau perbedaan budaya. Mayoritas penduduknya memiliki dasar budaya dan peradaban yang 
sama, tapi justru muncul dari kelompok etnis minoritas yang merasa tertindas oleh golongan yang lebih berkuasa.

Kedua, dunia yang makin menyempit mengakibatkan interaksi makin meningkat, sehingga pergesekan-pergesekan antar budaya dan peradaban makin kuat. Alasan keduanya ini nampaknya merupakan generalisasi pada tataran konsep. Meski ia menunjukkan bukti tentang budaya satu menolak budaya lain, misalnya kebencian orang Perancis terhadap pendatang Afrika Utara, namun banyak bukti dalam masyarakat dunia yang memiliki kesadaran budaya tinggi. Sebagai contoh komunitas Muslim di Amerika Serikat yang mulai menunjukkan peningkatan baik dalam kuantitas maupun persentuhannya dengan aspek ekonomi dan politik. Huntington sendiri seperti pura-pura tidak melihat bahwa di Amerika Serikat sudah jelas terlihat gerakan "budaya berganda" (multiculturalisme) yang mengakui bahkan merangkul semua peradaban yang diklasifikasikan Huntington tadi dalam tubuh masyarakat Amerika (Emmerson, 1993: 45).

Alasan ketiga, proses modernisasi ekonomi dan perubahan sosial dunia yang telah membuat masyarakat tercabut dari identitas lokal dan memperlemah negara bangsa sebagai sumber identitas mereka. Dalam hal ini agama muncul sebagai sumber identitas dan pegangan, sering dalam bentuk gerakan "fundamentalisme". Fundamentalisme ini sering disejajarkan dengan aktivitas politik, ekstrimisme, fanatisme, terorisme, dan anti-Amerika. Nampaknya makna seperti itu yang dipegangi oleh Huntington dalam mengartikan istilah fundamentalisme. Mungkin memang benar, bahwa sebagian terlibat dalam religio-politik radikal, namun menurut Esposito, yang terlihat dari kaum fundamentalisme justru bekerja dalam tatanan yang mapan. Esposito sendiri lebih memilih mengistilahkan " aktivisme Islam" atau "kebangkitan Islam" yang tidak terlalu dibebani oleh nilai-nilai yang berakar pada tradisi Islam, daripada istilah "fundamentalisme" yang terlalu dibebani oleh praduga Kristiani dan stereotip Barat dan juga menyiratkan ancaman monolitik yang tidak pernah ada (Esposito, 1996: 18). Kemajuan ilmu dan teknologi juga tidak jarang membawa bencana dan menimbulkan proses dehumanisasi. Fundamentalisme pada dasarnya menggiring perkembangan ilmu teknologi tersebut ke arah yang lebih humanis dengan cara mendekatkan nilai-nilai agama dengan unsur-unsur modernitas. Penekanan terhadap nilai-nilai yang sifatnya universal yang terkandung dalam ajaran agama, justru dapat mengurangi kemungkinan terjadinya konflik antar-peradaban. 
Di samping itu, Huntington juga 'mengabaikan' wacana keilmuan Islam yang plural. Tidak semua komunitas Muslim memberikan tanggapan kepada Barat dengan fundamentalismenya. Beberapa contohnya adalah pemikiran Seyyed Hossein Nasr, yang membagi gerakan Islam modern dalam empat kategori yaitu fundamentalisme, modernisme, mahdiisme, dan tradisionalisme (Nasr: 1987). Atau tulisan-tulisan Fazlur Rahman, Hasan Hanafi, Muhammad Arkoun, Bassam Tibi, dan sebagainya yang cenderung menggunakan cara pikir dengan meredefinisikan pandanganpandangan Islam, dengan menggunakan metodologi yang bersumber dari Barat.

Alasan keempat, terjadinya konflik peradaban akibat tumbuhnya kesadaran peradaban akibat benturan dengan dunia Barat. Yang dimaksud adalah Barat yang sedang berada di puncaknya berhadapan dengan non-Barat yang berkeinginan membentuk dunia dengan caracara mereka sendiri (de-westernisasi). Menurutnya, de-westernisasi ini justru terjadi di kalangan elite, sedangkan proses sebaliknya dapat ditemukan di kalangan rakyat biasa. Munculnya berbagai reaksi antiBarat pada dasarnya disebabkan oleh dominasi Barat dan kecenderungan nya untuk memaksakan kehendak dalam kancah perpolitikan internasional, terutama yang berkaitan dengan masalah demokrasi, HAM maupun lingkungan hidup. Benarkah kondisi ini akan memunculkan konflik peradaban, atau justru akan melahirkan akomodasi-akomodasi baru? Benarkah yang terjadi sekarang adalah demikian? Seandainya tesis ini benar, konsekuensi logis sebagai akibat dari perbedaan antara elite penguasa dan rakyat tentu tidak berakhir pada "kesatuan peradaban", melainkan pertentangan antar mereka sendiri. Dan kondisi di negara ketiga saat ini berada dalam dilema politik antara kubu rakyat melalui gerakan demokratisasinya dan kubu penguasa dengan sikap politik mempertahankan status quonya (Dewi Fortuna Anwar, 1993: 29).

Faktor kelima, karateristik dan perbedaan budaya kurang bisa menyatu dibanding dengan karateristik dan perbedaan politikekonomi. Ia mengatakan orang bisa menjadi separuh Perancis-separuh Arab, tapi sulit untuk menjadi setengah Muslim-setengah Katolik. Huntington ingin memperkuat pendapatnya bahwa perbedaan politikekonomi lebih memiliki dimensi terbuka dibandingkan dengan perbedaan budaya. Namun yang lebih penting diamati untuk saat ini adalah interaksi antarumat akan menimbulkan faktor saling ketergantungan. Begitu juga dalam agama-agama besar dunia, sadar akan tantangan yang dihadapi semakin berat, maka dialog-dialog 
antarumat beragama atau pola-pola kerukunan antaragama semakin diintensifkan, baik dalam bentuk dialog, seminar bahkan konferensi yang sifatnya internasional. Jadi menurut hemat penulis, penekanannya pada unsur verstehn lebih dibutuhkan, bagaimana budaya/agama satu memahami budaya/agama lain agar terhindar dari konflik peradaban.

Keenam, munculnya regionalisme ekonomi yang semakin meningkat. Di satu sisi, regionalisme ekonomi yang berhasil akan memperkuat kesadaran peradaban. Di pihak lain, regionalisme ekonomi hanya bisa berhasil kalau berakar dari budaya yang sama. Faktor ini mungkin faktor yang paling lemah di antara yang lain. Contohnya adalah Masyarakat Ekonomi Eropa dan ASEAN, keduanya lahir setelah terjadi konflik antar negara di kawasan yang bersangkutan, walaupun negara-negara yang terlibat konflik berasal dari peradaban yang sama. Kerjasama tersebut dilakukan agar masingmasing negara tidak melakukan perang. Dalam hal ini Huntington keliru menempatkan Jepang sebagai peradaban yang unik, yang hanya dianut orang Jepang sendiri. Jika Huntington menganggap bahwa Jepang tidak akan berbenturan dengan Barat, hal itu bukan berarti keberhasilan "pembaratan" atas Jepang, melainkan budaya Jepang sendiri yang mempunyai karakter berbeda. Bernard Lewis memberi tanggapan yang berbeda antara dunia Islam dan Jepang dalam menghadapi Barat. Ia mengatakan, "Persepsi kaum Muslim terhadap Eropa dipengaruhi dan didominasi sedemikian rupa oleh suatu unsur, yang bagi orang Jepang tidak ada, yaitu agama" (Bernard Lewis, 1988: 288). Dalam kasus Jepang, nampaknya Huntington kesulitan menempatkan teorinya, karena Jepang sesungguhnya bukan merupakan peradaban sebagaimana yang diklasifikasikannya, melainkan hanya entitas budaya saja.

\section{Analisis Seputar Tesis Huntington}

Ada hal yang menurut kacamata Barat menjadi sebuah ancaman besar yang harus dipertimbangkan, yaitu kebangkitan Islam. Saat ini Islam mulai bangkit kembali dalam satu semangat budaya yang "Islami" dan memiliki potensi jumlah penganut yang besar, serta memiliki kemampuan untuk memobilisasi penganutnya secara massal. Islam juga seringkali digambarkan sebagai ancaman lipat tiga: ancaman politik, ancaman peradaban, dan ancaman demografi (Esposito, 1987: 195). Cina - atau Asia pada umumnya - juga dianggap sebagai ancaman karena memiliki kekuatan pertumbuhan 
ekonomi yang sangat cepat. Secara umum, menurut Huntington, setidaknya terdapat tiga hal kecenderungan yang akan terjadi di masa depan, yaitu: 1) Era dominasi Barat yang semakin surut, 2) Berkembangnya kekuatan besar baru yang menolak nilai-nilai Barat karena menggunakan norma-norma mereka sendiri, 3) Perbedaan peradaban yang semakin jelas karena pengaruh pasar dan media (Stephen M. Walt, 1997: 179).

Bagi Huntington, posisi "Barat" dianggap sebagai suatu identitas tersendiri yang seakan-akan kokoh. Seperti yang dinyatakan oleh Fouad Ajami, dalam sebuah komentar tajam tentang risalah Huntington: "Barat itu sendiri tidak diperiksa dalam essensi Huntington. Tidak ada retakan yang melintasinya. Tak ada suara multikulturalis yang didengar. Ia tertib dalam kubunya sendiri“" (Gunawan Muhammad, 1994: 15). Nampaknya Huntington benarbenar mengabaikan di antara sesama manusia Barat di Eropa maupun Amerika Utara yang banyak mengalami ketegangan, termasuk konflik yang berlarut-larut antara budaya Protestan dan Katolik di Irlandia Utara, budaya Belanda dan Perancis di Belgia, serta budaya Inggeris dan Perancis di Canada (Emerson, 1993: 45). Maka peradaban yang dibayangkan Huntington, apalagi peradaban dengan identitas tertentu khususnya "Barat", adalah sebuah hasil pembersihan, penyingkiran, penyisihan, dan marjinalisasi.

Tesis tersebut secara tidak langsung memperkuat asumsi sebagian besar ilmuwan Barat yang melihat Islam sebagai aggression and hostility (agresi dan ancaman), dengan memberikan stereotipestereotipe yang sifatnya simplistic seperti, "Islam fanatik," "Islam militan," "Islam fundamentalis," dan seterusnya. Pendek kata, bagaimana Barat menciptakan stereotipe-stereotipe simplistis yang menunjukkan wajah the rage of Islam. Nampaknya terlalu sederhana untuk mengatakan Islam yang majemuk itu secara keseluruhan menentang dan berbenturan dengan Barat. Islam dalam penghayatan dan budayanya bukanlah merupakan suatu entitas tunggal (melainkan kompleksitas). Ia seperti juga agama-agama lain yang secara konstan terfragmentasi antara kekuatan yang mendorong modernisasi dan kekuatan tradisi lokal. Apa yang dilakukan Huntington lebih merupakan suatu simplifikasi atau dalam istilah Dewi Fortuna Anwar "Over Generalisasi".

Secara akademis, Huntington sebenarnya gagal mengidentifikasi nilai-nilai, institusi dan pola pikir sembilan peradaban yang ia klasifikasi. Pembagiannya juga tumpang tindih antara agama dan 
teritorial. Pemetaan yang ia lakukan merupakan wujud simplifikasi yang tidak berdasar.

Kritik paling tajam datang dari Edward Said (2001). Ia menilai Huntington tidak mengerti dinamika internal dan pluralitas setiap peradaban. Bagi Huntington, tantangan para pengambil keputusan di Barat adalah bagaimana membuat Barat semakin kuat dan menjaga peradaban lain agar tetap terkontrol terutama Islam. Bagi Said, Huntington adalah seorang ideolog yang sengaja membentuk 'peradaban' sebagai entitas yang terbungkus dan tak terpengaruh perubahan-perubahan interaksi sejarah manusia. Huntington tidak melihat bahwa peradaban itu mampu melakukan pertukaran budaya, bahkan bersama-sama membendung perang agama maupun imperialisme (http://swaramuslim.net/more.php?id=A266010M).

Sudah bukan saatnya lagi Barat menyikapi Islam (Muslim) sebagai the other, over there, karena populasi Muslim sudah menyebar begitu cepat. Populasi Muslim di Eropa dan Amerika meningkat dengan pesat justru terjadi pasca pengeboman WTC yang disinyalir pelakunya justru orang Islam. Tahun 2007 lebih dari 54 juta Muslim menetap di Eropa. Masjid sebagai sarana ibadah kaum Muslim, juga paralel dengan populasi ini. Dr. John L. Esposito, editor buku The Oxford History of Islam (Oxford University Press, London, 1999), dalam Bab "Introduction", mengatakan:

Meskipun Islam termuda di antara agama besar dunia, Islam merupakan agama terbesar kedua dan paling cepat pertumbuhannya di dunia. Pembicaraan tentang Dunia Islam hari ini merujuk bukan hanya kepada negeri-negeri yang membentang dari Afrika Utara ke Asia Tenggara tetapi juga kepada komunitas-komunitas Muslim yang ada di seluruh penjuru bumi”. http://irfananshory.blogspot.com/2007/04/ populasi-muslim-di-dunia.html).

Penciptaan "imajinasi" Islam tunggal, menyebabkan terjadinya reduksionisme keagamaan, yang memandang konflik politik AS -Irak yang memicu terjadinya perang AS - Irak dengan berakhir runtuhnya dinasti Saddam Hussein, atau kasus 11 September 2001 dengan Osama bin Laden sebagai kasus konflik antar agama yaitu Islam vs Kristen. Hal ini tentu tidak sepenuhnya benar, meskipun komunitas yang bertentangan adalah komunitas Muslim vs Kristiani, namun tidak bisa dikatakan bahwa Saddam Hussein adalah mewakili wajah Islam. Islam adalah agama yang plural dan kompleks. Harus disadari, bahwa tidak ada figur sentral - pasca Muhammad - yang bisa 
mewakili Islam secara keseluruhan. Melihat semua peristiwa di dunia Muslim melalui prisma Saddam Hussein, Osama bin Laden, atau Ayatullah Khomeini, adalah hal yang keliru. Hal inilah antara lain yang membawa Amerika - atau Barat pada umumnya - mempunyai perspektif yang salah mengenai Islam.

Secara akademis, belakangan muncul sarjana-sarjana Barat yang mengkaji Islam secara objektif, dengan menjadikan al-Quran dan Hadits sebagai sumber pertama dan utama. Di Amerika Serikat misalnya, ada Prof. John L. Esposito dan Prof. Michael Fischer; di Jerman juga ada ahli sufi, Annemarie Schimmel dan Dr. Murad Hofmann; di Inggris pun ada Prof. Francis Robinson, Prof. Hastings, dan lain-lain. Komentar mereka ini tidak saja simpatik, tetapi juga objektif oleh karena memakai metode go to the Source, to rely upon Muslim voice. Ketika pers dan sarjana Barat tempo dulu mengidentifikasikan Islam dengan terorisme, fundamentalisme, dan sejenisnya, maka yang seperti itu sekarang justru ditangkis ahli sufi terkemuka Jerman, Annemarie Schimmel sebagai "suatu hal yang sangat tragis." Bahkan, Dr. Murad Hofmann, intelektual terkemuka di Jerman, secara khusus menulis buku Islam The Alternative sebagai a scientific plea for Islam, yang bebas dari argumen apologetik.

\section{Penutup}

Tesis Huntington tersebut dapat diklasifikasikan ke dalam dua program, yaitu program jangka pendek dan program jangka panjang. Dalam program jangka pendeknya, dia secara serius memiliki obsesi untuk mempertahankan supremasi Barat melalui proyek pertentangan itu. Apabila ini diikuti oleh pemerintah - khususnya Barat -, hal ini akan menjadi sesuatu yang sangat membahayakan, karena dalam jangka pendek ia menganjurkan sikap konfrontatif terutama terhadap peradaban Islam. Namun, secara kontradiktif, jangka panjangnya Huntington menyarankan masing-masing peradaban yang berbeda untuk belajar hidup berdampingan (koeksistensi) satu sama lain. Yang menjadi pertanyaan, mungkinkah hidup berdampingan akan tercapai bila diawali dengan cara-cara yang konfrontatif?

Terlepas dari mana ide itu muncul, tesis Huntington ini menimbulkan pertanyaan luas di kalangan intelektual dan cendekiawan yang pada dasarnya mempertanyakan, mengapa ia mempergunakan paradigma kebudayaan untuk memahami dan meramalkan dinamika politik pasca Perang Dingin. Ia memang berusaha menjawab hal ini, namun, seperti diakuinya sendiri, bahwa 
teori ini merupakan hipotesis kasus terburuk. Justru karena ia tidak memperdulikan kenyataan yang berkembang di dunia saat ini.

Sejarah yang panjang memang ditandai oleh benturan-benturan antar peradaban. Tetapi ada kecenderungan sekarang bahwa yang menonjol adalah antaretnis, meskipun masing-masing etnis berada dalam satu peradaban yang sama. Perbedaan peradaban, terutama yang menyangkut masalah agama, tidak sepenuhnya menimbulkan benturan, karena pada masing-masing agama yang berbeda itu terdapat unsur-unsur universal yang dapat menyatukan perbedaan. Interaksi antar individu atau antar kelompok yang beda peradaban, tidak sepenuhnya menimbulkan konflik, malah justru dapat menciptakan suatu kondisi yang memungkinkan bagi akomodasi antar peradaban. Kemajuan dalam bidang komunikasi yang menghasilkan kedekatan dan persamaan pandangan, membuktikan adanya hubungan saling ketergantungan ketimbang permusuhan.

Tesis Huntington yang kontroversial ini lebih berperan sebagai provokator politik yang membawa dunia pada kondisi saling berbenturan. Dengan mendasarkan pada pendekatan teoritis yang baru, diharapkan para intelektual generasi berikutnya dapat "melampaui" tesis tersebut, dan menciptakan teori yang lebih membawa pada perdamaian dan keselamatan dunia. Dialog antarperadaban (dialogue of civilizations) sebagai alternatif nampaknya layak untuk dipertimbangkan daripada prediksi Huntington tentang benturan antarperadaban (clash of civilizations).

\section{Daftar Pustaka}

Dewi Fortuna Anwar. 1993. "Merosotnya Barat dan Kerisauan Huntington. Dalam Jurnal Ulumul Quran, No.5, Vol.IV, Tahun 1993.

Emmerson, Donald K. 1993. "Konflik Peradaban atau Fantasi Huntington?". Dalam jurnal Ulumul Qur'an, No.5, Vol.IV, Th. 1993.

1992. Dari The World Almanac and Book of Fact 1993. New York: Pharos Book.

Esposito, John L. 1996. Ancaman Islam, Mitos Atau Realitas? Edisi Revisi: Menggugat Tesis Huntington. Bandung: Mizan. 
Goenawan Muhammad. 1994 "Perspektif Pasca Modernisme atas Benturan Peradaban”. Dalam Ulumul Qur'an, No.1, Vol. V, 1994.

Huntington, Samuel P. 1996. The Clash of Civilization and Remarking of World Order. New York: Simon \& Schuster.

1993. "Benturan Antar Peradaban, Masa Depan Politik Dunia?". Terj. Saiful Muzani. Dalam jurnal Ulumul Qur'an, No. 5, Vol IV Th. 1993.

2004. Benturan Antar Peradaban dan Masa Depan Politik Dunia (The Clash of Civilizations and The Remarking of Word Order). Terj. M. Sadat Ismail. Yogyakarta: Qalam. Cet. VIII.

-------------. 2005. Amerika dan Dunia. Jakarta: Yayasan Obor Indonesia.

Lewis, Bernard. 1988. Muslim Menemukan Eropa. Terj. Ahmad Naimullah Muiz. Jakarta: Pustaka Firdaus.

Nasr, Seyyed Hossein. 1987. Traditional Islam in The Modern World. Kuala Lumpur: Foundation for Tradisional Studies.

Walt, Stephen M. 1997. "Building Up New Bogeymen". Dalam Jurnal Foreign Policy. Edisi Musim Semi, vol. 106.

http://swaramuslim.net/more.php?id=A266_0_1_0_M, (diakses tanggal 3 Februari 2009).

http://id.wikipedia.org/wiki/Peradaban (diakses tanggal 3 Februari 2009).

http://id.wikipedia.org/wiki/Samuel_Huntington (Diakses tanggal 20 Januari 2009).

http://irfananshory.blogspot.com/2007/04/populasi-muslim-di-dunia. html) (Diakses tanggal 10 Februari 2009).

Vita Fitria, M.Ag., dilahirkan di Kendal (Jawa Tengah), 2 Agustus 1971. Menamatkan Studi S-1 di Fakultas Syari'ah UIN Sunan Kalijaga Yogyakarta (1996), dan S-2 Program Studi Hukum Islam Pasca Sarjana UIN Sunan Kalijaga Yogyakarta (2004). Sejak tahun 2006 menjadi dosen Pendidikan Agama Islam Universitas Negeri Yogyakarta (UNY). 